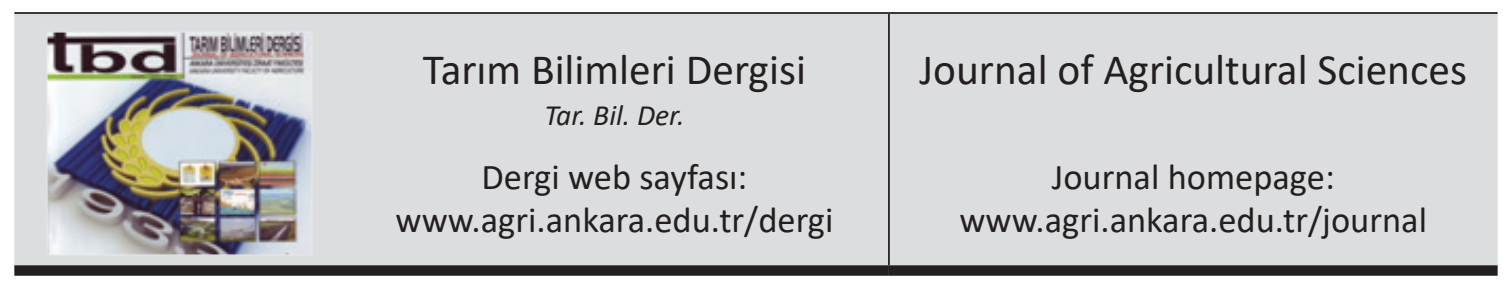

\title{
Introducing Different Cherry Cultivars to Inner and Crossover Areas
}

\author{
Hasan Cumhur SARISU, ${ }^{\mathrm{a}}$ Ömer Faruk KARAMÜRSEL ${ }^{\mathrm{a}}$, Fatma Pınar ÖZTÜRK ${ }^{\mathrm{a}}$, İsmail DEMİRTAŞ ${ }^{\mathrm{a}}$, \\ Hakkı KOÇAL ${ }^{a}$, İbrahim GÜR ${ }^{a}$, Özlem CENGIZZ ${ }^{\text {, İsmail ŞEVİK }}$

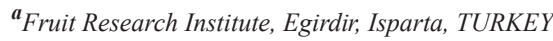 \\ ${ }^{b}$ Provincial Directorate of Ministry of Agriculture and Forestry, Mersin, TURKEY \\ ${ }^{c}$ Provincial Directorate of Ministry of Agriculture and Forestry, Isparta, TURKEY
}

\section{ARTICLE INFO}

Research Article

DOI: 10.15832 /ankutbd.538981

Corresponding Author: Hasan Cumhur SARISU, E-mail: hcumhurs@hotmail.com, Tel: +90 (246) 3132420

Received: 31 July 2017, Received in Revised Form: 13 December 2017, Accepted: 02 January 2018

\begin{abstract}
This study was carried out to evaluate quality, yield and phenology of some sweet cherry cultivars with different maturation periods in Isparta-Egirdir conditions. The study was carried out between 2000 and 2011, on Veysel, Précoce Bernard, Star, Venus, Mechlain Haimer, Summit, Techlovan, Fercer Arcina, Sylvia, Noire de Meched, Oktavia, Belge, 0900 Ziraat, Kordia, and Ferbolus. Venus, Bernard, Techlovan and Star cultivars were identified as the earliest blooming. Oktavia, Belge, Kordia and 0900 Ziraat cultivars were found to be the latest blooming cultivars. Generally; Veysel, Bernard and Star come to harvest maturity first. Venus, Mechlain Haimer, Summit, Techlovan, Fercer Arcina, Sylvia were found to be middle season cultivars, while N. De Meched, Oktavia, Belge, 0900 Ziraat, Kordia and Ferbolus were found to be the latest. Veysel early cherry cultivar were determined to be the most productive one, while late cultivar $\mathrm{N}$. De Meched and mid-season cultivar Techlovan were also found to be very efficient. In terms of fruit sizes; early sweet cherry cultivar P. Bernard, mid-season cultivar Summit and late season cultivar 0900 Ziraat gave the biggest fruits.

Keywords: Sweet cherry; Prunus avium; Fruit quality; Yield; Phenology
\end{abstract}

(C) Ankara Üniversitesi Ziraat Fakültesi

\section{Introduction}

Sweet cherry is among the most consumed fruits in the world. It has its own attractiveness, taste, aroma, flavor, and size. Besides, it is tastefully and easily eaten by everyone. For these reasons, it is a fruit the consumer insists on and readily consumes in both domestic and foreign markets. Therefore, it is one of the luxurious fruits that can find buyers at high prices in the market. For sweet cherry, demand is higher than supply almost every year. Consumers volunteer to pay higher prices for sweet cherry fruit (O'Rourke 2007). Despite all this, climate is the most important factor limiting sweet cherry production (Webster \& Loney 1996). All of these make cherry growing more advantageous than many other fruit species.

Sweet cherry production of the world is $2,294,455$ tons. The most important sweet cherry producer countries are Turkey (494,325 tons), USA (301,225 tons), Iran (200,000 tons), Italy (131,175 tons) and Uzbekistan (100,000 tons) (FAO 2015). Turkey, which is the leading country 
in the production of sweet cherries, exports about $10 \%$ of its production every year. The plans for the future are focused on increasing sweet cherry export. Ecological suitability affects the quality of production positively and provides a competitive advantage.

Sweet cherry has a wide range of consumption. However, as in the whole world, supply in Turkey is not sufficient even for fresh consumption, so the amount left for processing is very low and production is generally directed towards fresh consumption. Sweet cherries are grown in almost every region. However, commercial production is in Izmir, Afyon, Denizli, Manisa, Isparta, Konya, Bursa, Canakkale, Amasya. These provinces make up about $57.7 \%$ of the production (TUIK 2012). Sweet cherry is more attractive to the market when the fruit cultivar is less. For this reason domestic and foreign market buyers are able to pay high premium prices for quality sweet cherries. Highly priced sweet cherries make production attractive. As a result, sweet cherry production in Turkey expands and goes beyond the production areas mentioned above day by day without any basic study. Ekinci et al (2007) reported that positive developments experienced especially in recent years led to a rapid increase in the production of sweet cherries, 0900 Ziraat, among other cultivars exported, stood out with its superior quality characteristics, but the quantity of quality products was not sufficient in spite of the high production potential. Ozturk et al (2010) pointed out that the most important problem of the industry is the inadequacy of raw material supply and quality since the first day of Turkey's sweet cherry export. Similarly, Webster \& Looney (1996) and O'Rourke (2007) reported that the world is inadequate in terms of raw material supply in the sweet cherry industry and that future supply and quality of raw materials in the global sweet cherry industry will be important competition criteria. Although Turkey is one of the germplasm, the production of sweet cherry cultivars with high resistant transportation, which can meet the demands of foreign market other than 0900 Ziraat cultivar, has not been widespread. The choice of alternative cultivars for sweet cherry production in a region is determined by the effect of regional conditions. The productivity and quality of cultivars can vary from region to region. Climatic conditions particularly affect blooming and ripening season cultivars. In addition to its superior quality features, it also requires to focus on alternative cultivars, such as irregular production, inefficiency and other negative features, prolonging the supply season and diversifying the product.

For this purpose, it is very important to determine the morphological, phenological and pomological characteristics of domestic and foreign sweet cherry cultivars in different regions, to determine the cultivars that have high yield and quality, are in good agreement with the domestic and foreign market demands, and are well adapted to the regional conditions and other basic studies. In this study, adaptation ability of some important sweet cherry cultivars in Isparta-Egirdir conditions was evaluated; sweet cherry cultivars having different maturity periods and economical value were determined.

\section{Material and Methods}

\subsection{Orchard layout and plant materials}

The experiment was carried out in the field of Egirdir Fruit Research Institute (37 49'12.95"N; $30^{\circ} 52^{\prime} 13.73 " \mathrm{D}$; $921 \mathrm{~m}$ altitude) in the years 2000 2011.

Sweet cherry cultivars grafted onto Mazzard ( $P$. avium L.) seedling rootstock were planted spaced $6 \times 5 \mathrm{~m}$, in soil conditions characterized by loamy, calcareous (12\% total lime), alkaline ( $\mathrm{pH} 8.34)$. Trees were trained to a central leader and pruned in late winter and standard cultural practices. The orchard were irrigated with drip irrigation, fertilization applications were made with fertigation.

In the study Veysel, Précoce Bernard $\left(\mathrm{S}_{3} \mathrm{~S}_{9}\right)$, Star, Venus, Mechlain Haimer, Summit, Techlovan $\left(\mathrm{S}_{1} \mathrm{~S}_{3}\right)$, Fercer Arcina $\left(\mathrm{S}_{2} \mathrm{~S}_{6}\right)$, Sylvia $\left(\mathrm{S}_{1} \mathrm{~S}_{4}\right)$, Noire de Meched, Oktavia, Belge $\left(\mathrm{S}_{3} \mathrm{~S}_{4}\right), 0900$ Ziraat, Kordia, Ferbolus sweet cherry cultivars were used. 


\subsection{Determination of phenological stages of cultivars}

The phenological observations and yields in this study include data between 2006 and 2011 following juvenility. Phenological observations of the cultivars were made following the period of juvenility. Phenological observation dates were recorded as bud burst, first bloom, full bloom, bloom end and harvest date. Bud burst and petal fall dates were noted according to Chapman \& Catlin (1976). The time of $70 \%$ and $5 \%$ of blooms opened was noted as respectively full and first bloom dates. Fadón et al (2015) characterized the phenology of some sweet cherry varieties and adapted to 97 numerical $\mathrm{BBCH}$ codes, and framed flower development within the growth stages. According to researchers, phenological stages (BBCH scale) were defined as follows: bud burst-stage 53; first bloom-stage 61; full bloom-stage 65; and petal fall-stage 69. Harvest time, however, was recorded as the date when the cultivars reached harvest maturity according to stage 87 reported by Fadón et al (2015). Harvest times were grouped as early, mid-season and late.

\subsection{Determination the yields of the cultivars}

The yield of the cultivars was taken as yield $(\mathrm{kg})$ per tree per year following juvenility. Average yield per tree, cumulative yield and cumulative yields per unit area $\left(\mathrm{kg} \mathrm{ha}^{-1}\right)$ were calculated. In the last year of the experiment, the cumulative yield of the trunk section area was determined $\left(\mathrm{kg} \mathrm{cm}^{-2}\right)$.

\subsection{Determination of some fruit characteristics of cultivars}

In the last two years of the experiment (2010-2011), pomological analyzes of the cultivars were carried out and the differences among the cultivars were determined.

Pomological analyzes were performed with 20 fruits sampled each time. Fruit weight $(\mathrm{g})$, width $(\mathrm{mm})$, length $(\mathrm{mm})$, stone weight $(\mathrm{g})$, stalk length $(\mathrm{mm})$ and stalk weight $(\mathrm{g})$ were measured using standard methods. Fruits were measured by soluble solid content (SSC, \%-refractometer), total acidity (TA, titrated with $0.1 \mathrm{~N} \mathrm{NaOH} ; \%$ ), fruit juice $\mathrm{pH}$, fruit firmness (with hand penetrometer using 4.5 mm tip).

\subsection{Statistical analysis}

The experimental design was a randomized blocks, 5 replicates using a single tree. Statistical analyses were performed using the JMP statistical software package (vers 8; SAS Inst. Inc., Cary, NC, USA). Mean separation was performed using LSD's multiple range test at $\mathrm{P}<0.01$ level.

\section{Results and Discussion}

\subsection{Determination of phenological stages of cultivars}

When the first blooming dates were compared, it was determined that the cultivars of Venus, Bernard, Techlovan and Star were the earliest blooming. Overall, it was observed that Oktavia, Belge, Kordia and 0900 Ziraat cultivars were in the late-blooming group. It can be said that cherry cultivars generally bloomed between $3^{\text {rd }}$ week and $4^{\text {th }}$ week of April in Egirdir ecology in terms of full blooming dates. The blooming end dates of cultivars were generally between the end of April and the beginning of May. A distribution parallel to the first blooming and full blooming dates was observed among the cultivars (Figure 1).

The blooming time varies depending on the cultivar and climate. In this respect, determination of the time and duration of blooming of the cultivars depending on the region and cultivar is a very important issue for the production of sweet cherries, which is a problem of incompatible which is especially required to use a pollinator cultivar. The cultivars in our study are able to pollinate each other. Because the blooming duration of the cultivars coincides with each other in groups. However, an early blooming cultivar cannot be recommended as pollinator for a late blooming cultivar. In our study, Oktavia $\left(\mathrm{S}_{1} \mathrm{~S}_{3}\right)$, Summit $\left(\mathrm{S}_{1} \mathrm{~S}_{2}\right)$ and Kordia $\left(\mathrm{S}_{3} \mathrm{~S}_{6}\right)$ cultivars can be used as pollinator to each other since the blooming time with 0900 Ziraat cultivar is at the same time with each other. As a matter of fact, Sar1su et al (2016a) 


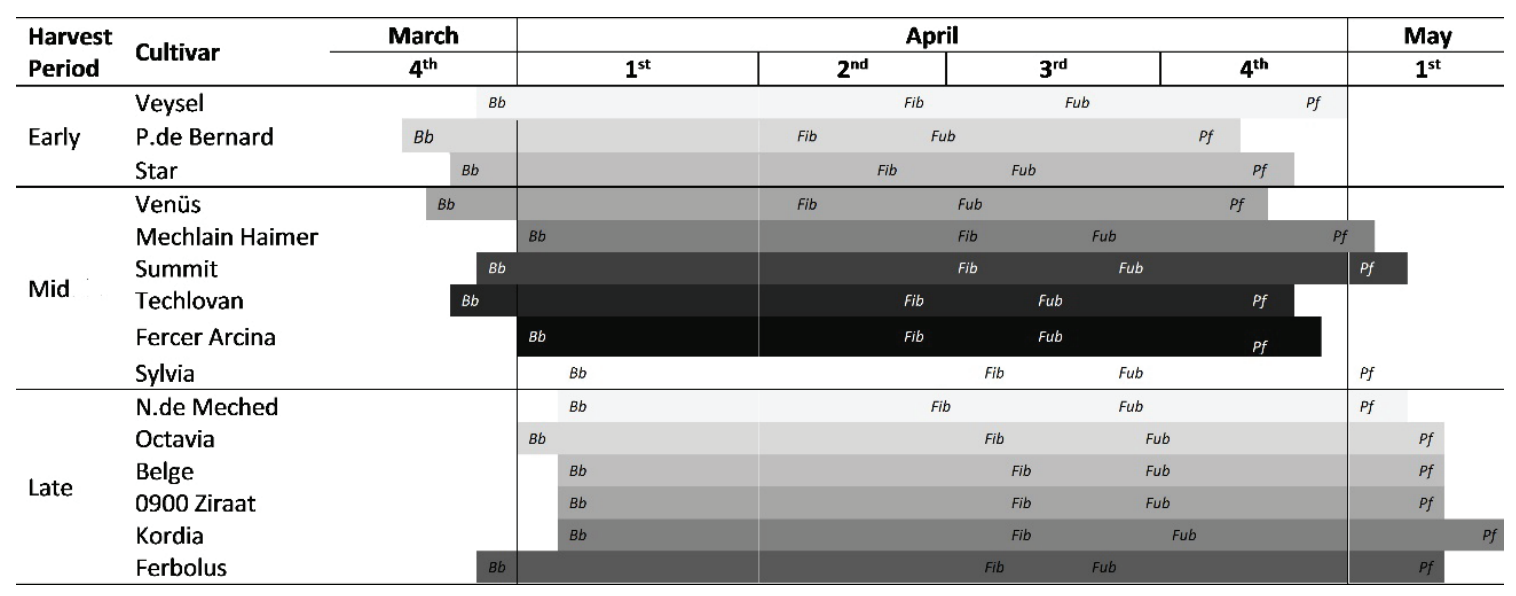

Figure 1- Blooming period of sweet cherry cultivars in average six years. Bb, bud burst; Fib, first bloom; $F u b$, full bloom; $P f$, petal fall

reported that Kordia $(23.28 \%)$ and Summit $(22.28 \%)$ and Oktavia $(12.59 \%)$ gave very good results in the 0900 Ziraat as pollinator and found that the pollinating capacities of these cultivars were generally high. However, since N. de Meched and 0900 Ziraat, which are good efficiency in the study, are in the same incompatible group $\left(22^{\text {nd }}\right.$ incompatible group- $\mathrm{S}_{3} \mathrm{~S}_{12}$ ) (Schuster 2012) they cannot pollinate each other. Similarly, although the blooming times of the Venus and Star cultivars coincide, they cannot be pollinate with each other because they are in the second group $\left(\mathrm{S}_{1} \mathrm{~S}_{3}\right)$ incompatible (Schuster 2012) group. For this reason, as many researchers have noted (Choi \& Andersen 2001; Wünsch \& Hormoza 2004; Beyhan \& Karakaş 2009; Ipek et al 2011; Schuster 2012), cultivars should be preferred, in which both blooming times and incompatible groups are appropriate when setting up a sweet cherry orchard.

In the study, the harvesting times of sweet cherry cultivars are shown in Figure 2, and the blooming and handling times (visual) are given in Figure 3. It was seen that the cultivars in the experiment generally provided a harvest advantage from the beginning of June until the beginning of July in Egirdir ecology. Generally, the cultivars of Veysel, Bernard and Star come to the first harvest maturity. As mid-season cultivars, Venus,
Mechlain Haimer, Summit, Techlovan, Fercer Arcina, Sylvia, the latest cultivars of the harvest maturity are N. de Meched, Oktavia, Belge, 0900 Ziraat, Kordia, Ferbolus. When the harvest dates are considered; for Egirdir ecology, the cultivars in the experiment did not maintain continuity in the $2^{\text {nd }}$ week of harvest during the 4 week harvest period. During the first, third and fourth weeks, the harvesting period could be closed with different cultivars (Figure 2). It is very important that the sweet cherry fruits maturity on the tree almost at the same time and therefore the harvesting process should be completed in a short time without losing much time. In addition, the sweet cherry harvest is very difficult and requires lots of labor. For these reasons, if the sweet cherry orchard has to be established in large areas, it is economically advantageous for growers that the harvesting times of the appropriate cultivars are different from each other. For example, in our study, establishing sweet cherry orchard in large areas with two types of combination Mechlain Haimer and Summit, Techlovan and Fercer Arcina, 0900 Ziraat and Kordia will not be economically viable for this region. The different harvesting times of the cultivars will contribute to the diversification of cultivars in the production regions. 


\begin{tabular}{|c|c|c|c|c|c|}
\hline \multirow{2}{*}{$\begin{array}{l}\text { Harvest } \\
\text { Period }\end{array}$} & \multirow{2}{*}{ Cultivars } & \multicolumn{4}{|c|}{ June (week) } \\
\hline & & $1^{\text {st }}$ & $2^{\text {nd }}$ & $3^{\text {rd }}$ & $4^{\text {th }}$ \\
\hline \multirow{3}{*}{ Early } & Veysel & & & & \\
\hline & P. Bernard & & & & \\
\hline & Star & & & & \\
\hline \multirow{6}{*}{ Mid. } & Venus & & & & \\
\hline & Mechlain Haimer & & & & \\
\hline & Summit & & & & \\
\hline & Techlovan & & & & \\
\hline & Fercer Arcina & & & & \\
\hline & Sylvia & & & & \\
\hline \multirow{6}{*}{ Late } & N.de Meched & & & & \\
\hline & Oktavia & & & & \\
\hline & Belge & & & & \\
\hline & 0900 Ziraat & & & & \\
\hline & Kordia & & & & \\
\hline & Ferbolus & & & & \\
\hline
\end{tabular}

Figure 2- Harvest period of sweet cherry cultivars in average six years

\subsection{Determination of yields of cultivars}

The yields per tree and cumulative yields of cultivars following 6 years juvenility are given Table 1 .

As a result of the analysis of variance in terms of cumulative yield, the differences between the cultivars were found significant $(\mathrm{P}<0.01)$. It was determined that the most productive cultivars of the earliest cultivars of Veysel among all cultivars (147.86 $\mathrm{kg}^{-1}$ ) and P. Bernard cultivar, which is also an early cultivars, has the lowest yield cultivar $\left(35.96 \mathrm{~kg}^{-1}\right)$. N. de Meched, which is a latest cultivar, and Techlovan

Table 1- Yield $\left(\mathrm{kg} \mathrm{tree}^{-1}\right)$ and cumulative yield of sweet cheery (2006-2011)

\begin{tabular}{llllllll}
\hline \multirow{2}{*}{ Cultivars } & \multicolumn{7}{c}{${\text { Yield }\left(\mathrm{kg} \text { tree }^{-1}\right)}$} \\
\cline { 2 - 8 } & 2006 & 2007 & 2008 & 2009 & 2010 & 2011 & Cumulative \\
\hline Veysel & 1.54 & 4.20 & 5.22 & 26.15 & 63.95 & 46.80 & $147.86 \mathrm{a}^{* *}$ \\
P.de Bernard & 0.58 & 1.46 & 5.53 & 9.28 & 10.94 & 8.17 & $35.96 \mathrm{de}$ \\
Star & 0.80 & 2.12 & 5.41 & 10.40 & 18.48 & 38.96 & $76.17 \mathrm{~cd}$ \\
Venüs & 1.11 & 5.10 & 0.50 & 6.20 & 16.00 & 7.20 & $36.11 \mathrm{de}$ \\
Mechlain Haimer & 1.60 & 6.32 & 2.33 & 14.18 & 54.23 & 53.33 & $131.99 \mathrm{ab}$ \\
Summit & & 2.03 & 0.64 & 7.60 & 9.50 & 8.76 & $28.53 \mathrm{de}$ \\
Techlovan & 6.53 & 13.97 & 3.28 & 18.00 & 39.27 & 52.67 & $147.64 \mathrm{a}$ \\
Fercer Arcina & 0.78 & 1.08 & 0.50 & 5.00 & 3.00 & 9.25 & $19.61 \mathrm{e}$ \\
Sylvia & & 2.35 & 3.00 & 14.40 & 25.70 & 19.53 & $64.98 \mathrm{c}-\mathrm{e}$ \\
N. de Meched & 1.64 & 10.34 & 8.39 & 27.12 & 44.80 & 55.00 & $147.29 \mathrm{a}$ \\
Oktavia & 0.84 & 3.78 & 6.13 & 21.92 & 25.06 & 35.75 & $93.48 \mathrm{bc}$ \\
Belge & 0.70 & 4.88 & 5.13 & 14.25 & 20.02 & 19.05 & $64.03 \mathrm{c}-\mathrm{e}$ \\
0900 Ziraat & 1.48 & 11.55 & 8.99 & 15.50 & 26.00 & 16.20 & $79.72 \mathrm{~b}-\mathrm{d}$ \\
Kordia & 3.63 & 3.40 & 2.49 & 19.81 & 17.50 & 20.35 & $67.18 \mathrm{c}-\mathrm{e}$ \\
Ferbolus & 1.20 & 2.58 & 8.85 & 27.81 & 41.80 & 33.60 & $115.835 \mathrm{a}-\mathrm{c}$ \\
\hline
\end{tabular}

**, means within cultivars with the same letter are not significantly different by LSD's Multiple Range Test at $\mathrm{P}<0.01$ 


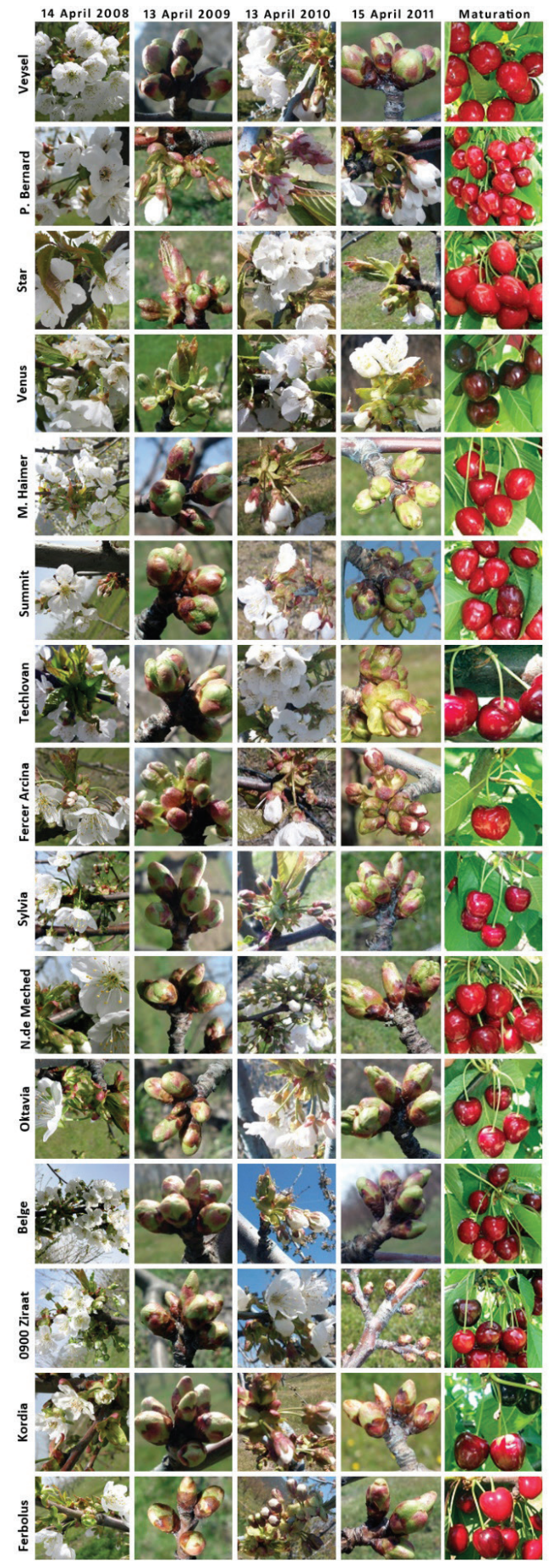

Figure 3- Phenological periods of sweet cherry cultivar, which are mid-season cultivars, appear to be second and third among all cultivars in efficiency (Table 1). The middle season cultivar Fercer Arcina was identified as the least efficient cultivar after P. Bernard cultivar. In the late season cultivars, 0900 cultivars were the lowest yield (79.72 $\mathrm{kg}^{-1}$ ). In our study, we used 0900 Ziraat and Kordia, besides some other foreign cultivars which not much information have been given about the productivity of them. For this reason, our findings show originality in terms of yield efficiencies. Our findings are similar to some other studies for Kordia and 0900 Ziraat cultivars (Lichev et al 2004; Stehr 2008; Grzyb \& Rozpara 2009; Sarısu et al 2016b).

The yield per cross section area $(\mathrm{P}<0.01)$ and trunk cross sections $(\mathrm{P}<0.05)$ of the experimented sweet cherry cultivars were found to be statistically significant (Table 2). The largest cross-sectional area was observed in Ferbolus $\left(567.02 \mathrm{~cm}^{2}\right)$ while Kordia cultivar (316.28 $\mathrm{cm}^{2}$ ) had lowest cross-sectional area. While the highest

Table 2- Yield efficiencies of sweet cherry cultivars (2016)

\begin{tabular}{|c|c|c|c|}
\hline Cultivars & $\begin{array}{l}\text { Trunk section } \\
\text { area } \\
\left(\mathrm{cm}^{2}\right)\end{array}$ & $\begin{array}{l}\text { Yield per unit } \\
\text { cross-sectional } \\
\text { area } \\
\left(\mathrm{kg} \mathrm{cm}^{-2}\right)\end{array}$ & $\begin{array}{l}\text { Cumulative } \\
\text { yield } \\
\text { per unit area } \\
\left(t h a^{-1}\right)\end{array}$ \\
\hline Veysel & $378.78 b-e^{*}$ & $0.40 \mathrm{ab}^{* *}$ & $48.79 a^{* *}$ \\
\hline $\begin{array}{l}\text { Précoce } \\
\text { Bernard }\end{array}$ & $533.30 \mathrm{a}-\mathrm{c}$ & $0.07 \mathrm{fg}$ & $11.87 \mathrm{e}-\mathrm{g}$ \\
\hline Star & $361.76 c-e$ & $0.21 \mathrm{c}-\mathrm{e}$ & $25.13 \mathrm{c}-\mathrm{f}$ \\
\hline Venus & 466.52a-e & $0.10 \mathrm{e}-\mathrm{g}$ & $11.92 \mathrm{e}-\mathrm{g}$ \\
\hline $\begin{array}{l}\text { Mechlain } \\
\text { Haimer }\end{array}$ & $542.73 \mathrm{ab}$ & $0.26 \mathrm{~cd}$ & $43.56 \mathrm{ab}$ \\
\hline Summit & $390.41 b-e$ & $0.08 \mathrm{fg}$ & $9.42 \mathrm{fg}$ \\
\hline Techlovan & 358.99de & $0.47 \mathrm{a}$ & $48.72 \mathrm{a}$ \\
\hline Fercer Arcina & $471.14 \mathrm{a}-\mathrm{e}$ & $0.04 \mathrm{~g}$ & $6.47 \mathrm{~g}$ \\
\hline Sylvia & 459.99a-e & $0.25 \mathrm{~cd}$ & $38.64 a-c$ \\
\hline $\begin{array}{l}\text { Noire de } \\
\text { Meched }\end{array}$ & $450.12 \mathrm{a}-\mathrm{e}$ & $0.30 \mathrm{bc}$ & $48.61 \mathrm{a}$ \\
\hline Oktavia & $514.59 \mathrm{a}-\mathrm{d}$ & $0.18 \mathrm{~d}-\mathrm{f}$ & $30.85 b-d$ \\
\hline Belge & 441.90a-e & $0.18 \mathrm{~d}-\mathrm{f}$ & $21.13 \mathrm{~d}-\mathrm{g}$ \\
\hline 0900 Ziraat & $335.49 \mathrm{e}$ & $0.25 \mathrm{~cd}$ & $26.31 \mathrm{c}-\mathrm{e}$ \\
\hline Kordia & $316.28 \mathrm{e}$ & $0.22 \mathrm{c}-\mathrm{e}$ & $22.17 \mathrm{~d}-\mathrm{g}$ \\
\hline Ferbolus & $567.02 \mathrm{a}$ & $0.21 \mathrm{c}-\mathrm{e}$ & $38.23 \mathrm{a}-\mathrm{c}$ \\
\hline
\end{tabular}

*, means within cultivars with the same letter are not significantly different by LSD's Multiple Range Test at $\mathrm{P}<0.05$; **, means within cultivars with the same letter are not significantly different by LSD's Multiple Range Test at $\mathrm{P}<0.01$ 
the unit area cumulative yield are $48.79 \mathrm{t} \mathrm{ha}^{-1}$ with Veysel and $48.72 \mathrm{t} \mathrm{ha}^{-1}$ with Techlovan, these cultivar were included in the same group in the analysis of variance. The cumulative yield per unit cross-sectional area was at most Techlovan $(0.47 \mathrm{~kg}$ $\left.\mathrm{cm}^{2}\right)$ then Veysel $\left(0.40 \mathrm{~kg} \mathrm{~cm}^{2}\right)$ and in the statistical analysis, the Techlovan cultivar is different from the Veysel cultivar. The Fercer Arcina has the lowest both in unit area cumulative yield and cumulative yield per unit cross-sectional area (Table 2).

\subsection{Determination of some fruit characteristics of cultivars}

The most important criteria that are mentioned as fruit quality factors in cherries are; fruit weight, fruit shape, fruit firmness, stalks remain green for a long time, taste, fruit color, SSC and TA (Kader 1983; Younce \& Davis 1985; Drake \& Fellman 1987; Fischer et al 1996). In this respect, when we studied some fruit quality properties of fruits, Sweet cherry fruit size were found to be statistically significantly at the sweet cherry cultivars at different harvesting periods $(\mathrm{P}<0.05)$ (Figure 4$)$. Among the early cherry cultivars in terms of fruit sizes, P. Bernard cultivar showed the best results. P. Bernard was the largest cultivar in the early with fruit weight (7.39 g) and fruit diameter $(24.67 \mathrm{~mm})$. Fruit size increased in mid and late season cultivars. Among the midseason cultivars, the largest fruit was obtained Summit (11.21 g) cultivar. Also, Fercer Arcina and Sylvia of the same period cultivars were large enough to be ignored with $9.34 \mathrm{~g}$ and $9.25 \mathrm{~g}$ fruit weights respectively.

The most important export cultivar of Turkey among the late period cultivars was found to be 0900 Ziraat which gave statistically significant fruit weight $(10.11 \mathrm{~g})(\mathrm{P}<0.01)$. Oktavia $(9.03 \mathrm{~g})$ and Belge $(8.91 \mathrm{~g})$ were also found to be important cultivars in terms of size (Figure 4). Kappel et al (1996) giving the model of 'ideal' of sweet cherry cultivar, state that it should have the weight of fruit 11-12 g. Crisosto et al (2003) stated that the size of the fruit determines the crop, quality and acceptance of the cultivar by the customers. In our study also, ideal weight cultivars were Summit and 0900 Ziraat.

Sweet cherry cultivars stone, fruit stalk and some fruit chemical characteristic were given Table 3 . Stone weights were found statistically significant at sweet cherries $(\mathrm{P}<0.05)$. The bigger stone weight

Table 3- Fruit stone, fruit stalk and some chemical characteristic of sweet cherry cultivars

\begin{tabular}{|c|c|c|c|c|c|c|c|}
\hline \multirow{2}{*}{$\begin{array}{c}\text { Harvest } \\
\text { period }\end{array}$} & \multirow{2}{*}{ Cultivars } & \multirow{2}{*}{$\begin{array}{l}\text { Stone } \\
\text { Weight (g) }\end{array}$} & \multicolumn{2}{|c|}{ Fruit stalk } & \multicolumn{3}{|c|}{ Some chemical characteristic } \\
\hline & & & Weight $(g)$ & Length $(\mathrm{mm})$ & $p H$ & $S S C(\%)$ & $T A(\%)$ \\
\hline \multirow{3}{*}{ Early } & Veysel & $0.273 \mathrm{~d}^{* *}$ & $0.107 \mathrm{e}^{*}$ & $45.32 \mathrm{ef}^{* *}$ & 3.77 & 14.17 & $0.71 \mathrm{e}-\mathrm{g} * *$ \\
\hline & Précoce Bernard & $0.447 b$ & $0.135 \mathrm{a}-\mathrm{e}$ & $48.72 b-e$ & 3.82 & 12.77 & $0.55 \mathrm{~g}$ \\
\hline & Star & $0.547 \mathrm{a}$ & $0.126 \mathrm{c}-\mathrm{e}$ & $41.06 \mathrm{f}$ & 3.71 & 12.52 & $0.58 \mathrm{~g}$ \\
\hline \multirow{6}{*}{ Mid } & Venus & $0.349 \mathrm{~cd}$ & $0.117 \mathrm{de}$ & $32.84 \mathrm{~g}$ & 3.75 & 14.72 & $0.70 \mathrm{e}-\mathrm{g}$ \\
\hline & Mechlain Haimer & $0.463 \mathrm{ab}$ & $0.149 \mathrm{a}-\mathrm{d}$ & $52.67 \mathrm{a}-\mathrm{d}$ & 3.52 & 13.59 & $0.93 a-c$ \\
\hline & Summit & $0.454 \mathrm{~b}$ & $0.140 \mathrm{a}-\mathrm{e}$ & $41.32 \mathrm{f}$ & 3.94 & 14.03 & $0.85 b-f$ \\
\hline & Techlovan & $0.387 \mathrm{bc}$ & $0.115 \mathrm{de}$ & $32.19 \mathrm{~g}$ & 3.79 & 14.63 & $1.04 \mathrm{a}$ \\
\hline & Fercer Arcina & $0.453 b$ & $0.161 \mathrm{a}-\mathrm{c}$ & $45.64 d-f$ & 3.61 & 14.95 & $0.89 a-d$ \\
\hline & Sylvia & $0.443 b$ & $0.145 \mathrm{a}-\mathrm{e}$ & $46.92 c-f$ & 3.79 & 15.18 & $0.81 \mathrm{c}-\mathrm{f}$ \\
\hline \multirow{6}{*}{ Late } & Noire de Meched & $0.456 b$ & $0.168 \mathrm{ab}$ & $55.91 \mathrm{a}$ & 4.01 & 14.34 & $0.72 \mathrm{~d}-\mathrm{g}$ \\
\hline & Oktavia & $0.417 \mathrm{bc}$ & $0.152 \mathrm{a}-\mathrm{d}$ & $54.34 \mathrm{ab}$ & 3.96 & 13.04 & $0.81 \mathrm{c}-\mathrm{f}$ \\
\hline & Belge & $0.414 \mathrm{bc}$ & $0.129 \mathrm{~b}-\mathrm{e}$ & $52.29 \mathrm{a}-\mathrm{e}$ & 3.96 & 13.69 & $0.83 b-f$ \\
\hline & 0900 Ziraat & $0.466 \mathrm{ab}$ & $0.174 \mathrm{a}$ & $55.94 a$ & 4.04 & 15.47 & $0.69 \mathrm{f}-\mathrm{g}$ \\
\hline & Kordia & $0.417 \mathrm{bc}$ & $0.163 a-c$ & $53.74 a-c$ & 3.95 & 14.40 & $0.87 \mathrm{a}-\mathrm{e}$ \\
\hline & Ferbolus & $0.434 \mathrm{bc}$ & $0.135 \mathrm{a}-\mathrm{e}$ & $47.22 b-f$ & 3.87 & 15.50 & $0.99 \mathrm{ab}$ \\
\hline
\end{tabular}

*, means within cultivars with the same letter are not significantly different by LSD's Multiple Range Test at $\mathrm{P}<0.05$; **, means within cultivars with the same letter are not significantly different by LSD's Multiple Range Test at $\mathrm{P}<0.01$ 


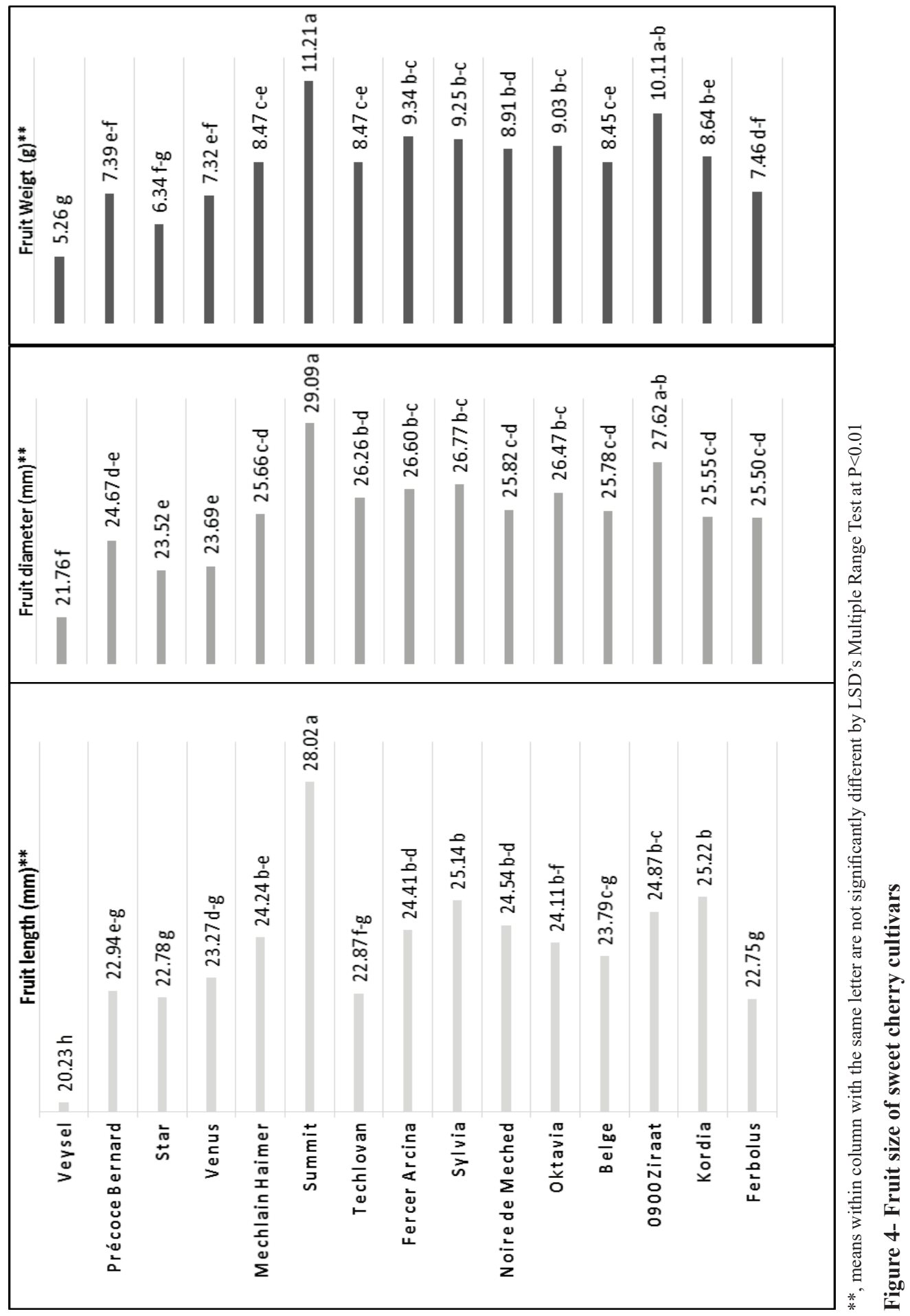


was determined Star $(0.547 \mathrm{~g}), 0900$ Ziraat $(0.466$ g) and Meclain Haimer $(0.463 \mathrm{~g})$ cultivars. It was determined to have the smallest stone $(0.273 \mathrm{~g})$ parallel to the fruit size of the Veysel cultivar. Fruit stalk length is an important characteristic for postharvest strength and ease of harvest. Longer stalk is better than shorter one because of easier picking and lesser tendency to decay and cracking of the fruit (Stojanovic et al 2012). According to Schick $\&$ Toivonen (2000) short and green stalk reminds buyers on freshness and juiciness of the fruit. In our study, fruit stalk length $(\mathrm{P}<0.01)$ and fruit stalk weight $(\mathrm{P}<0.05)$ were found statistically significant among the sweet cherry cultivars. Mechlain Haimer, Noir de Meched, Oktavia, Document, 0900 Ziraat and Kordia cultivars were statistically analyzed by variance analysis $(\mathrm{P}<0.01)$. And these cultivars are $5 \mathrm{~cm}$ long and have the longest stalk cultivars with fruit stalk. Venus (32.84 mm) and Techlovan (32.19 $\mathrm{mm}$ ) are the shortest stalk cultivars.

Although there was no statistical difference between $\mathrm{pH}$ and SSC values among the cultivars in the study, TA was found to be statistically significant $(\mathrm{P}<0.01)$ (Table 3). Meclain Haimer, Techlovan, Fercer Arcina, Kordia and Ferbolus cultivars have high SSC. In general, early cultivars were found to have lower SSC. The original fruit colors and SSC were taken into consideration when the harvest time of the cultivars was decided. The SSC of the cultivars generally ranged between 12$16 \%$ (Table 3). Main factor of fruit quality, is the content of soluble solids (Crisosto et al 2003). It depends on many factors, and mostly on the cultivar (Gonçalves et al 2006), rootstock (Usenik et al 2010) and stages of fruit ripeness (Drake \& Elfving 2002). According to Kappel et al (1996) the 'ideal' of sweet cherry cultivars would be the one having the content of soluble solids between $17 \%$ and $19 \%$. The differences between our results and results of other authors can be explained by the influence of different rootstock, soil and climate conditions, cultural practices, and stage of maturity (Drake \& Elfving, 2002; Crisosto et al 2003).

\section{Conclusions}

In conclusion, in Isparta-Egirdir ecology, as a result of this study carried out with different cherry cultivars, Mechlain Haimer, Techloven and Sylvia midseason cultivars, Oktavia, N. De Meched, Kordia, 0900 and Belge late season cultivars were found to be advisable. The Early Veysel cultivar is not recommended for this region because of its low fruit quality, although it gave the highest yield.

\section{Acknowledgements}

This study was financially supported by the General Directorate of Agricultural Research and Policies of Turkey (TAGEM).

\section{References}

Beyhan N \& Karakaş B (2009). Investigation of the fertilization biology of some sweet cherry cultivars grown in The Central Northern Anatolian Region of Turkey. Scientia Horticulturae 121(3): 320-326

Chapman P J \& Catlin G A (1976). Growth stages in fruit trees-from dormant to fruit set. Plant Science, New York's Food and Life Sciences Bulletin 58: 1-12

Choi C \& Andersen R L (2001). Variable fruit set in self-fertile sweet cherry. Canadian Journal of Plant Science 81: 753-760

Crisosto C H, Crisosto G M \& Metheney P (2003). Consumer acceptance of 'Brooks' and 'Bing' cherries is mainly dependent on fruit SSC and visual skin color. Postharvest Biology and Technology 28: 159167

Drake S R \& Fellman J K (1987). Indicators of maturity and storage quality of Rainier sweet cherry Indicateurs de maturité et d'aptitude à l'entreposage des cerises douces Rainier. HortScience 22(2): 283-285

Drake S R \& Elfving D C (2002). Indicators of maturity and storage quality of 'Lapins' sweet cherry. HortTechnology 12(4): 687-690

Ekinci N, Delice A, Gür E \& Özdüven F (2007). Değişik dozlarda kalsiyum uygulamalarının 0900 Ziraat kiraz çeşidinin kalite kriterleri üzerine etkileri. Türkiye $V$. Ulusal Bahçe Bitkileri Kongresi Bildiriler: 4-7 Eylül, Erzurum, s. 464-468 
Fadón E, Herrero M \& Rodrigo J (2015). Flower development in sweet cherry framed in the $\mathrm{BBCH}$ scale. Scientia Horticulturae 192: 141-147

FAO (2015). Food and agriculture organization of the United Nations. Visited on February of 2017. http:// faostat.fao.org

Fischer R R, Von Elbe J H, Schuler R T, Bruhn H D \& Moore J D (1996). Some physical properties of sour cherries. Transactions of the American Society of Agricultural and Biological Engineers pp. 175-179

Gonçalves B, Moutinho-Pereira J, Santos A, Silva A P, Bacelar E, Correia C \& Rosa E (2006). Scionrootstock interaction affects the physiology and fruit quality of sweet cherry. Tree Physiology 26(1): 93104

Grzyb Z S \& Rozpara E (2009). Effect of various rootstocks and tree spacing on the size of Vanda. Acta Horticulturae 814: 401-404

Ipek A, Gulen H, Akçay M E, Ipek M, Ergin S \& Eris A (2011). Determination of self-incompatibility groups of Sweet Cherry Genotypes from Turkey. Genetics and Molecular Research 10(1): 253-260

Kader A A (1983). Post-harvest quality maintenance of fruits and vegetables in developing countries. PostHavest Physiology and Crop Production, Plenum, New York, pp. 455-470

Kappel F, Fisher-Fleming B \& Hogue E (1996). Fruit characteristics and sensory attributes of an ideal sweet cherry. HortScience 31(3): 443-446

Lichev V, Govedarov G \& Tabakov S (2004). Evaluation of sweet cherry cultivars recently introduced into Bulgaria compared with two Bulgarian cultivars. Journal of Fruit and Ornamental Plant Research 286(12): 281-286

O'Rourke D (2007). World Cherry Review, A Publication of Belros Inc. Ortega

Ozturk P, Kacal E, Sarısu C, Karamursel D \& Emre M (2010). Economic evaluation of preharvest and harvest losses in 0900 Ziraat sweet cherry cultivar. Acta Horticulturae 877: 261-267

Sarısu H C, Gür İ \& Cengiz Ö Y (2016a). 0900 Ziraat kiraz çeşidi için kaliteli tozlayııı çeşitler. VII. Ulusal
Bahçe Bitkileri Kongresi Bildirileri Bahçe (Özel Say1) Cilt I: Meyvecilik 45: 1234-1238

Sarısu H C, Karamürsel Ö F, Gür İ, Koçal H, Cengiz Ö Y, Demirtaş İ \& Ozturk F P (2016b). The performance of '0900 Ziraat' sweet cherry cultivar on different rootstocks. Acta Horticultural Proceedings, III. Balkan Symposium on Fruit Growing, 16-18 September, pp. 167-172

Schick J L \& Toivonen P M A (2000). Optimizing cherry stem quality. En: $16^{\text {th }}$ Annual Postharvest Conference, Yakima, WA, March 14-15 de Marzo, pp. 4

Schuster M (2012). Incompatible $(S-)$ genotypes of sweet cherry cultivars (Prunus avium L.). Scientia Horticulturae 148: 59-73

Stehr R (2008). Further experiences with dwarfing sweet cherry rootstocks in Northern Germany. Acta Horticulturae 795: 185-190

Stojanovic M, Milatovic D, Kulina M \& Zlatka AlicDzanovic Z (2012). Pomological properties of sweet cherry cultivars on Gisela 5 rootstock in the region of Sarajevo. Third International Scientific Symposium “Agrosym Jahorina 2012”. 10.7251/AGSY1203183S UDK 634.1/.7(497.15 Sarajevo) pp. 183-187

TUIK (2012). Crop production statistics (online). Turkish Statistical Institute, http:/www.tuik.gov.tr/ bitkiselapp/bitkisel.zul. Visited on February of 2017, Ankara

Usenik V, Fajt N, Mikulic-Petkovsek M, Slatner A, Stampar F \& Veberic R (2010). Sweet cherry pomological and biochemical characteristics influenced by rootstock. Journal of Agricultural and Food Chemistry 58: 4928-4933

Webster A D \& Loney N E (1996). Cherries Crop Physiology, Production and Uses. (Ed: Webster AD, Looney NE), World Distribution of Sweet and Sour Cherry Production, National statistics. Cab International, USA, pp. 25-69

Wünsch A \& Hormaza J I (2004). S-Allele Identification by PCR analysis in sweet cherry cultivars. Plant Breeding 123: 327-331

Younce F L \& Davis D C (1985). A Dynamic sensor for cherry firmness. Transactions of the American Society of Agricultural and Biological Engineers 38(5): 14671476 